\title{
WIND ENERGY LOCATION PREDICTION BETWEEN METEOROLOGICAL STATIONS USING ANN
}

\author{
MARAN P.S. ${ }^{1, *}$ \\ PONNUSAMY R. ${ }^{2}$ \\ VENKATESAN R. ${ }^{3}$ \\ SINGH A.B. ${ }^{4}$
}

Received: 28/06/2014

Accepted: 13/01/2015

Available online: 17/02/2015

\author{
${ }^{1}$ Scientist-D, Centre for Earth \& Atmospheric Sciences \\ Sathyabama University, Chennai, India \\ ${ }^{2}$ Principal, Rajiv Gandhi College of Engineering \\ Sriperumbudur, Chennai, India \\ ${ }^{3,4}$ Radiological Safety Division, Indira Gandhi Centre for Atomic Research \\ Kalpakkam, Tamilnadu, India
}

*to whom all correspondence should be addressed: e-mail: sardarmaran@gmail.com

\section{ABSTRACT}

Wind Energy is one of the most important sources of renewable energy. There is a need to develop the availability of wind energy in the field where there is no measured wind velocity information. For this type of situation, it seems to be necessary to predict the wind energy potential using such as wind speed using artificial neural network (ANN) method. Soft computing techniques are widely used now days in the study of wind energy potential estimation. In this work, the wind energy potential between neighborhood meteorological tower stations was predicted using Artificial Neural Network technique. One of the most suitable regions of Tamil Nadu for wind power generation was located in the districts of Tirunelveli, Thoothukudi, Kanyakumari, Theni, Coimbatore, and Dindigul. Along the southeast coastline of Tamil Nadu, there are no valleys and mountains besides the mountains are situated away from the sea coast in many regions. Therefore, these regions are exposed to northerly winds that are not as strong as the southerly winds.

Keywords: Wind Speed, Wind Energy, Artificial Neural Network, ANN, Soft Computing, Meteorological Tower

\section{Introduction}

Tamil Nadu is the eleventh largest state in India with an area of $130,058 \mathrm{~km}^{2}$ [50,216 sq mi] and is the seventh most populated state with a population of $66,396,000$. It is the fourth largest contributor to India's GDP and the most urbanized state in India. The state has the highest number (10.56\%) of business enterprises in India compared to its population share of about 6\%. Tamil Nadu was lately emerged as the most literate state in India as announced by Ministry of Human Resource Development (MHRD). The top 13 cities in Tamil Nadu are Chennai, Coimbatore, Madurai, Trichy, Salem, Erode, Tirunelveli, Tirupur, Vellore, Tuticorin, Thanjavur, Nagercoil and Dindigul (Janakiraman et al., 2013). These cities were built-up with the presence of large and small industries that uses electricity as a main source of energy for manufacturing their products. The demand for power in these cities are growing. According to the Tamil Nadu Energy Development Agency (TEDA), the nodal agency for the promoting renewable energy sector, 
the State has 5,055 MW of wind generation capacity now with private investors accounting for about 5,038 MW. About $17 \mathrm{MW}$ is with the Tamil Nadu Electricity Board and TEDA. The amazing growth of wind power in the past ten years is attributable to a multiplicity of enabling factors, including the evolution of a conducive policy and regulatory framework. The good thing is that the transition to renewable sources of energy has begun, and this transition is being led by wind power (Pillai G.M. et al., 2006).

Tamil Nadu is endowed with three lengthy mountain ranges on the Western side with a potential of 1650 MW in Palghat pass in Coimbatore District, $1300 \mathrm{MW}$ in Shengottai pass in Tirunelveli District and 2100 MW in Aralvoimozhi pass in Kanyakumari District and $450 \mathrm{MW}$ in other areas totaling $5500 \mathrm{MW}$ (Jayabalan P., 2009). There are 41 Wind potential sites in eight districts in the state, according to the Wind assessment studies carried out by TEDA with the funding assistance of MNRE and the State Government. With this programme identification, high wind prone zones with annual mean wind speed of $18 \mathrm{~km} / \mathrm{hr}$ and annual mean Wind Power Density (WPD) of $150 \mathrm{~W} / \mathrm{m}^{2}$ at $50 \mathrm{~m}$ height was undertaken by TEDA with financial assistance from Ministry of New and Renewable Energy (MNRE). Wind farms have so far been set up in 26 sites of the above, almost entirely by the private sector, except $19 \mathrm{MW}$ of Demonstration Wind farms in 8 locations set up during 1986 to 1993, jointly by TEDA and TNEB, but now run and maintained by TNEB. The total installed capacity of wind mills in the state including the $19 \mathrm{MW}$ under public sector is $4287 \mathrm{MW}$ (8451 Machines) as on 31 March 2009. The total installed Wind capacity as on 30.06.2012 is 7055.475 $\mathrm{MW}$, contributing to $40 \%$ of country's total wind capacity. Wind capacity addition to a tune of $1000 \mathrm{MW}$ is expected for 2012-13. (Energy Department, Government of Tamil Nadu)

\section{Study Area}

In this study, the ANN method was applied in the prediction of monthly wind speed of any target station at a location with no measurement, which is referred to as the target station from the measurements of a set of surrounding stations. Figure 1. Shows the map of new location between meteorological stations from Google earth.

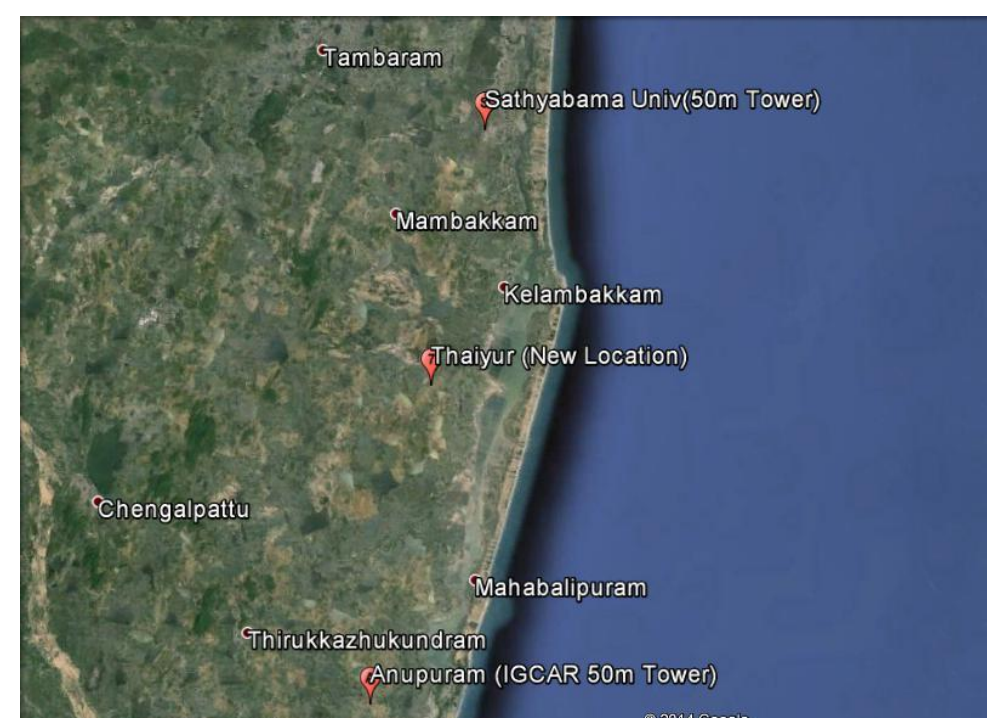

Figure 1. Map of the new location between Metrological Stations (Google Earth)

This study was applied for regional wind speed prediction in the area of Thaiyur (New location) in the south east coastal area of Tamil Nadu. The location is between two meteorological stations namely Sathyabama University $50 \mathrm{~m}$ Tower and Anupuram $50 \mathrm{~m}$ Meteorological station. The latitude is $12^{\circ} .7388^{\prime}$ and longitude 
is $80^{\circ} .1748^{\prime}$. The elevation of the new location is $41 \mathrm{ft}$ from the sea level. In order to estimate a target station, the correlation coefficient was obtained for each pair of wind speed time series of all stations and weighting factors between the pivot station and its surrounding stations were determined by artificial neural network technique.

Table 1. Meteorological Tower locations

\begin{tabular}{cccccc}
\hline Station & Latitude (N) & Longitude (E) & Elevation & $\begin{array}{c}\text { Distance } \\
\text { from Sea }\end{array}$ & $\begin{array}{c}\text { Anemometer } \\
\text { Height }\end{array}$ \\
\hline $\begin{array}{c}\text { Sathyabama University } \\
\text { 50m Tower }\end{array}$ & $12^{\circ} .8731^{\prime}$ & $80^{\circ} .2158^{\prime}$ & $6 \mathrm{ft}$ & $3.85 \mathrm{~km}$ & $16 \mathrm{~m}$ \\
\hline Thaiyur (New Location) & $12^{\circ} .7388$ & $80^{\circ} .1748$ & $41 \mathrm{ft}$ & $7.05 \mathrm{~km}$ & - \\
\hline Anupuram 50m Tower & $12^{\circ} .5643$ & $80^{\circ} .1277$ & $46 \mathrm{ft}$ & $6.13 \mathrm{~km}$ & $16 \mathrm{~m}$ \\
\hline
\end{tabular}

\section{Methodology}

The Meteorological data have been used in several kinds of analyses with different goals. Meteorological towers are the platform providing continuous in situ information within the lower atmospheric layer. The 50 Metre tower at Sathyabama University and Anupuram Kalpakkam has multilevel sensors for all the basic atmospheric parameters like wind speed $(2 \mathrm{~m}, 8 \mathrm{~m}, 16 \mathrm{~m} \& 50 \mathrm{~m})$ wind direction $(2 \mathrm{~m}, 8 \mathrm{~m}, 16 \mathrm{~m} \& 50 \mathrm{~m})$, temperature $(2 \mathrm{~m}, 8 \mathrm{~m}, 16 \mathrm{~m}, 50 \mathrm{~m})$, relative humidity $(2 \mathrm{~m}, 8 \mathrm{~m}, 16 \mathrm{~m}, 50 \mathrm{~m})$, atmospheric pressure and rainfall. The ten minutes interval of weather data at the ground level $(2 \mathrm{~m})$ for the year of 2008 to 2012 were collected from 50m Meteorological towers of Sathyabama University and Anupuram, Kalpakkam in the south east coastline of Tamil Nadu. The frequency distribution of wind speed and wind direction sectoral Frequencies of wind direction, variations of daily, monthly and yearly mean wind speed, standard deviations are calculated.

\subsection{Artificial Neural Network}

Artificial neural networks are effective and reliable algorithms capable of performing functional input/output mappings. Their parallel, multi-parametric characters, and computing speed, make them a powerful computational tool especially when the underlying physical mathematical models are complicated. ANN are also known as universal approximations. Information is processed in a nonalgorithmic way. Knowledge is acquired through learning that means ANN can be used to model complex systems in which mathematical descriptions are not available (Zhen-hai Guo et al., 2011).

A simplified model of a neural network is machine that is designed in the way in which the brain performs a particular task or function of interest; the network is usually implemented using electronic components or simulated in software on a digital computer (Gong Li et al., 2011). During the past 15 years there has been a substantial increase in the interest on artificial neural networks. ANN have been applied successfully in various fields of mathematics, engineering, medicine, economics, meteorology, psychology, and many others (Ch. Jyosthna et al., 2012). They have been used in a wide range of applications including pattern classification, function approximation, optimization, prediction and automatic control and many other engineering problems. This method learned from given examples by constructing an input-output mapping in order to perform predictions. In other words, to train and test a neural network, input data and corresponding output values are necessary. ANN was trained to overcome the limitations of the conventional approaches to solve complex problems that are difficult to model analytically. 


\subsection{WAsP Program}

In this study, Wind Atlas Analysis and Application Program (WAsP) was used to investigate wind characteristics of sites. WAsP program and associated software were developed by Riso National Laboratory, Denmark. WAsP is a PC program for the vertical and horizontal extrapolation of wind climate statistics. It contains several models to describe the wind flow over different terrains and close to sheltering obstacles. WAsP consists of five main calculation blocks such as, analysis of raw data, generation of wind atlas data, wind climate estimation, estimation of wind power potential and calculation of wind farm production.

\subsection{Weibull Distribution}

Generally, previously measured wind data are used for the estimation of wind power potential at any site. First of all, at any location, hourly wind speeds and wind directions are observed and monitored. These results were used for frequency and probability modeling. Wind speed data in time-series format is usually arranged in the frequency distribution format since it is more convenient for statistical analysis. Therefore, the available time-series data were translated into frequency distribution format. The wind speed probability distributions and the functions representing them mathematically are the main tools used in the wind related literature (Nabiha BRAHMI et al., 2010). Their use includes a wide range of applications, from the techniques used to identify the parameters of the distribution functions to the use of such functions for analyzing the wind speed data and wind energy economics.

There are various methods to establish an adequate statistical model for obtaining the wind speed frequency distribution, which may later be used for predicting the wind energy potential. The Weibull distribution is widely accepted to give a good fit for wind energy applications.

\subsection{Wind Energy Potential}

The wind energy potential can be calculated by using the following formula

$$
\mathrm{P}=\frac{1}{2} \rho A V^{3}
$$

Where $\mathrm{P}=$ Power (Watts)

$\rho=$ Air Density (about $1.225 \mathrm{~kg} \mathrm{~m}^{-3}$ at sea level)

$A=$ Swept Area of Blades $\left(\mathrm{m}^{2}\right)$

$\mathrm{V}=$ Velocity of the wind

\section{Results and Discussion}

\subsection{Frequency distribution of wind speed}

The frequency distribution of the wind speeds help to find: How long is a wind power plant out of action in the case of lack of wind? What is the range of most frequent wind speeds? The hourly wind speed is higher than $3 \mathrm{~m} / \mathrm{s}$ that is $68 \%$ higher in Sathyabama University meteorological station, $40 \%$ higher in Anupuram Kalpakkam Meteorological Station. The following figures $2 \& 3$ shows the wind speed frequencies of both towers. 


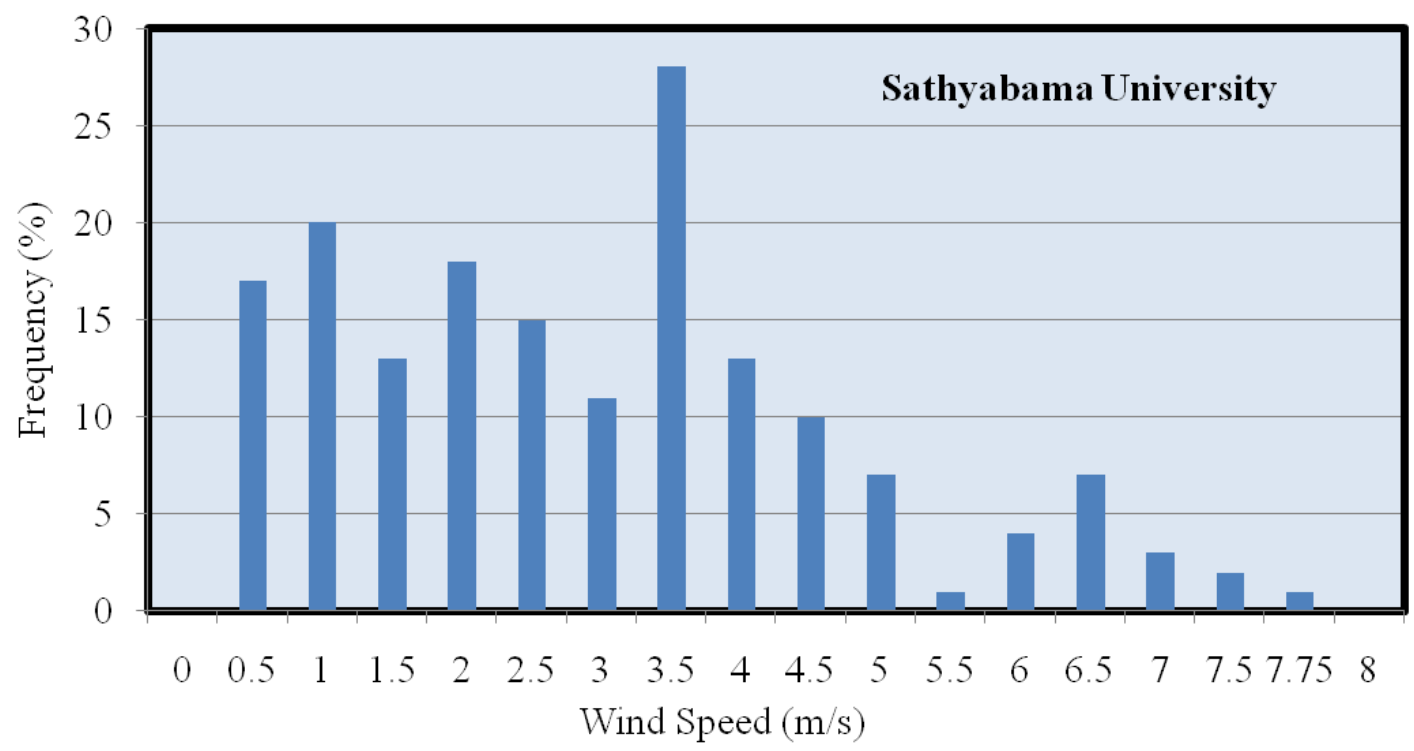

Figure 2. Wind speed frequency distribution of Sathyabama University tower

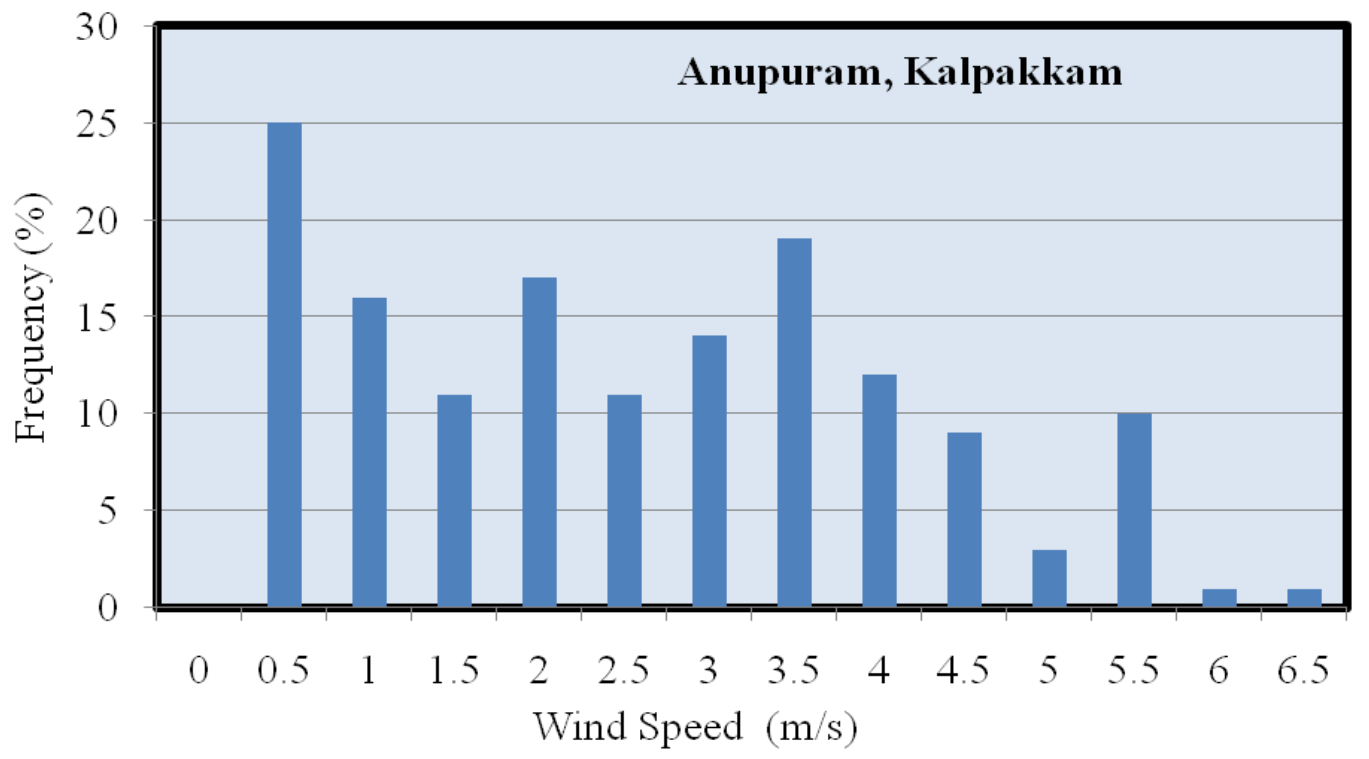

Figure 3. Wind speed frequency distribution of Anupuram Meteorological tower

\subsection{Sectoral frequencies of wind direction}

The direction of wind is crucially important for the evaluation of the possibilities of utilizing wind power. Table 2. Shows the sectoral frequencies of wind direction for the weather stations. According to this estimation the dominant prevailing wind directions at Sathyabama University are $30^{\circ}, 90^{\circ}$ and $270^{\circ}$. For Anupuram tower the dominant wind directions are at $180^{\circ}$ and $270^{\circ}$.

There are two important aspects for investigating wind energy potential of a site. They are wind speed distribution in each direction and the most frequent wind directions. Besides the level and structure of wind speeds, the direction of wind is decisive significance for the evaluation of the possible wind power (Philippopoulos et al., 2012). The following figure $4 \& 5$. Shows the wind direction frequencies of weather stations for the years 2012-2013. 
Table 2. Sectoral Frequencies of Wind Direction at Meteorological Stations

\begin{tabular}{|l|c|c|}
\hline \multirow{2}{*}{ Direction } & \multicolumn{2}{|c|}{ Frequency (\%) } \\
\cline { 2 - 3 } & Sathyabama University & Anupuram, Kalpakkam \\
\hline $\mathrm{N}\left(0^{\circ}\right)$ & 17.2 & 5.7 \\
\hline $\mathrm{NE}\left(30^{\circ}\right)$ & 21.0 & 5.8 \\
\hline $\mathrm{EN}\left(60^{\circ}\right)$ & 2.7 & 0.9 \\
\hline $\mathrm{E}\left(90^{\circ}\right)$ & 22.4 & 4.0 \\
\hline $\left.\mathrm{ES} 120^{\circ}\right)$ & 1.9 & 1.4 \\
\hline $\mathrm{SE}\left(150^{\circ}\right)$ & 9.6 & 3.2 \\
\hline $\mathrm{S}\left(180^{\circ}\right)$ & 1.9 & 13.3 \\
\hline $\mathrm{SW}\left(210^{\circ}\right)$ & 3.2 & 4.8 \\
\hline $\mathrm{WS}\left(240^{\circ}\right)$ & 8.6 & 9.5 \\
\hline $\mathrm{W}\left(270^{\circ}\right)$ & 26.8 & 32.1 \\
\hline $\mathrm{WN}\left(300^{\circ}\right)$ & 5.4 & 3.1 \\
\hline $\mathrm{NW}\left(330^{\circ}\right)$ & 15.2 & 21.4 \\
\hline
\end{tabular}

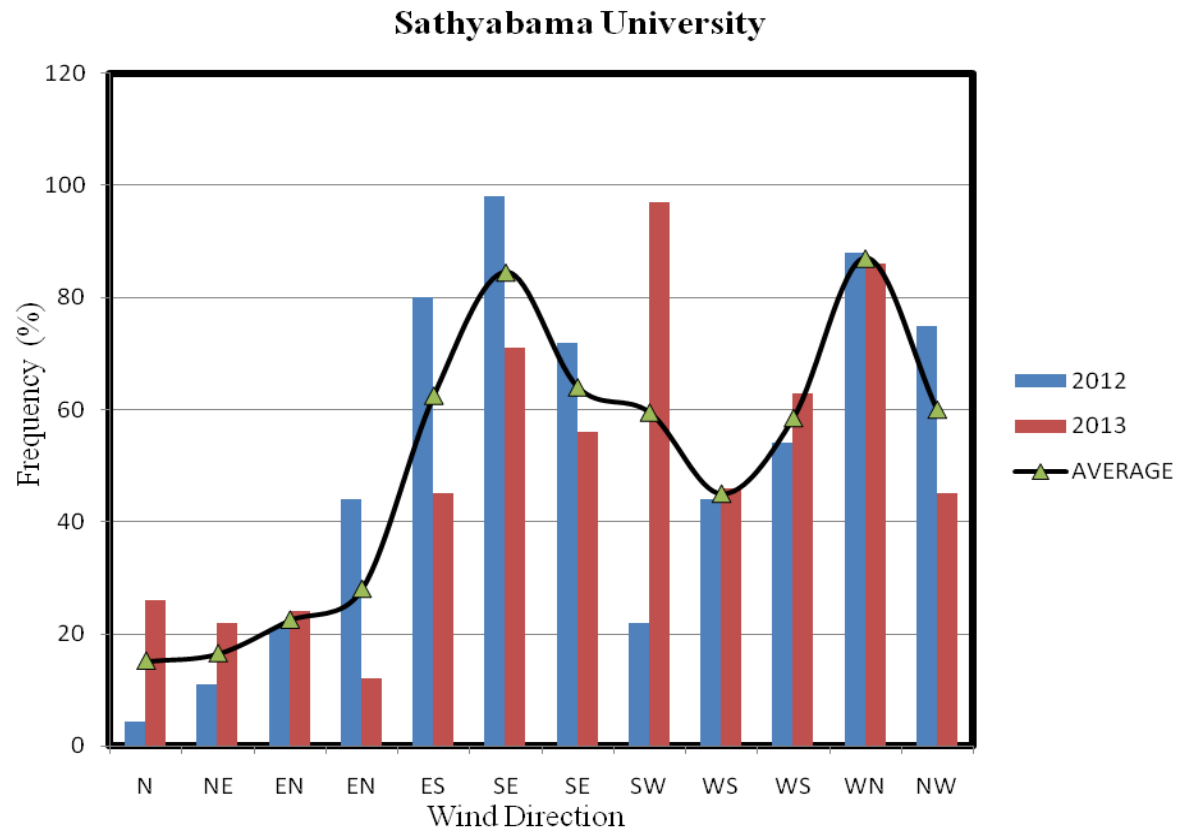

Figure 4. Wind direction Frequency of Sathyabama University tower

\subsection{Annual wind power density and Weibull parameter estimation}

The problem of wind energy is essentially dependent on the magnitude and regularity of wind speeds. For this purpose, monthly mean wind speed $\left(v_{m}(\mathrm{~m} / \mathrm{s})\right)$ and Standard deviation of wind speeds $(\sigma(\mathrm{m} / \mathrm{s}))$ for all weather stations were determined. The wind speed is more than $3 \mathrm{~m} / \mathrm{s}$ at during March to June. The Annual Wind power density distributions are compared with least square, WAsP with the actual data is as shown in Table 3. The $\mathrm{R}$ squared value for these comparisons gives a significant result as shown in the Table 4. 


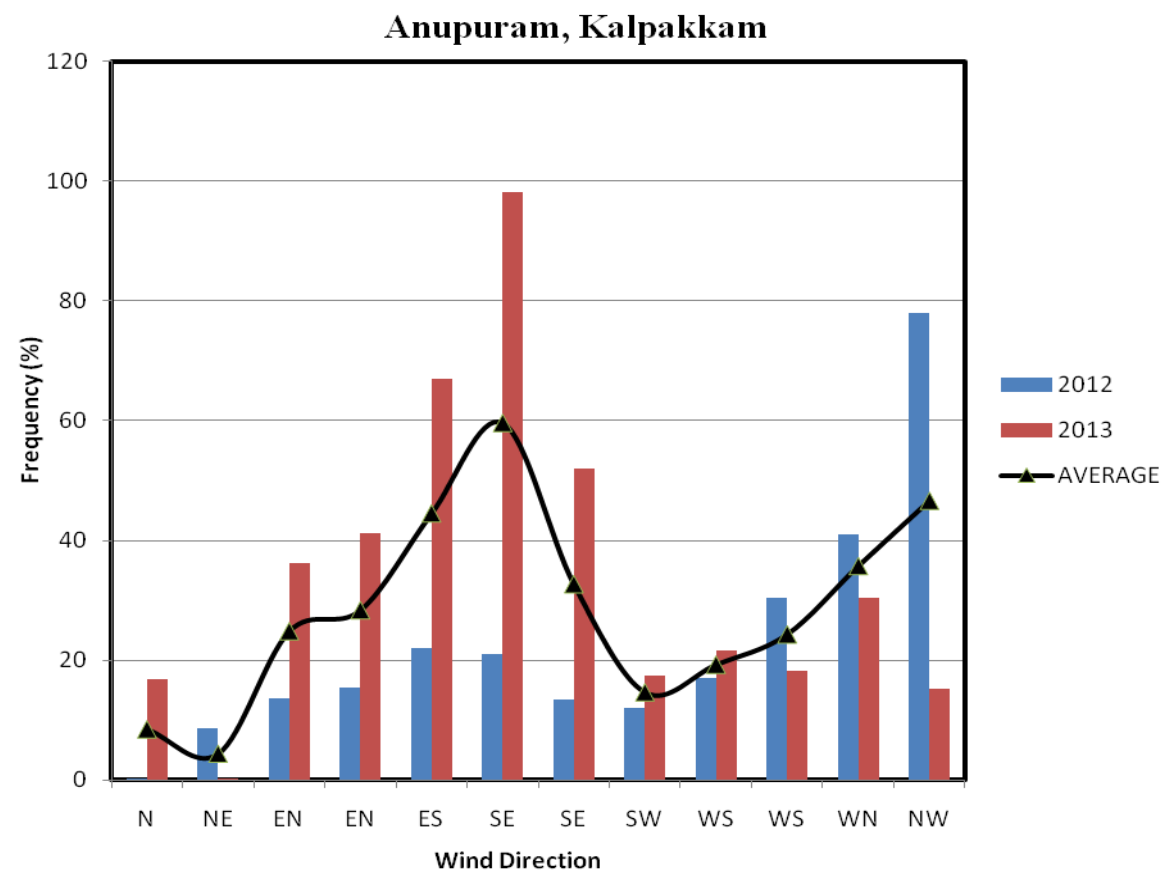

Figure 5. Wind direction frequency of Anupuram tower

Table 3. Annual Wind power density distributions

\begin{tabular}{ccccc}
\hline \multirow{2}{*}{ Station } & \multicolumn{4}{c}{ Wind power Density } \\
\cline { 2 - 5 } & Maximum likelihood & Least squares & \multirow{2}{*}{ WAsP } & \multirow{2}{*}{ Actual data } \\
\hline Sathyabama University & 16.9 & 18.9 & 15.4 & 16.4 \\
\hline Anupuram, Kalpakkam & 18.9 & 17.8 & 19.4 & 17.4 \\
\hline
\end{tabular}

Table 4. $\mathrm{R}$ Squared Value of Wind power densities for all stations

\begin{tabular}{lccc}
\hline \multirow{2}{*}{ Station } & \multicolumn{3}{c}{ R Squared } \\
\cline { 2 - 4 } & Maximum likelihood & Least squares & WAsP \\
\hline $\begin{array}{l}\text { Sathyabama } \\
\text { University }\end{array}$ & 0.76829 & 0.77536 & 0.70908 \\
\hline $\begin{array}{l}\text { Anupuram, } \\
\text { Kalpakkam }\end{array}$ & 0.72244 & 0.71487 & 0.67561 \\
\hline
\end{tabular}

The Weibull shape parameters ( $k$ ) for wind speed are within the range 1.9-2.1 for the whole year. The Weibull scale parameters for wind speed(c) also vary between $2.4 \mathrm{~m} / \mathrm{s}$ and $2.9 \mathrm{~m} / \mathrm{s}$ as shown in Table 5 .

Table 5. Weibull parameter values

\begin{tabular}{lcccc}
\hline Station & $\begin{array}{c}\text { Weibull Parameter } \\
\text { (c) }\left(\mathrm{m} \mathrm{s}^{-1}\right)\end{array}$ & $\begin{array}{c}\text { Weibull Parameter } \\
(\mathrm{k})\end{array}$ & $\begin{array}{c}\text { Mean } \\
\text { Wind Speed } \\
\left(\mathrm{m} \mathrm{s}^{-1}\right)\end{array}$ & $\begin{array}{c}\text { Mean Energy } \\
\text { Density } \\
\left(\mathrm{W} \mathrm{m} \mathrm{m}^{-2}\right)\end{array}$ \\
\hline $\begin{array}{l}\text { Sathyabama } \\
\text { University }\end{array}$ & 2.4 & 1.9 & 2.4 & 15.4 \\
\hline $\begin{array}{l}\text { Anupuram, } \\
\text { Kalpakkam }\end{array}$ & 2.8 & 2.1 & 2.6 & 22.4 \\
\hline
\end{tabular}




\subsection{Wind energy location prediction using ANN}

\subsubsection{Wind energy prediction of target station}

This network consists of an input layer, two hidden layers and an output layer. The mean monthly wind speed of reference station and corresponding month were used in the input layer of the network. Anupuram meteorological station was selected as a reference station. The significant point in the selection of reference station was a good relation with high correlation coefficient between the target station and reference station. Resilient propagation (RP) learning algorithm was used in the present simulation. Neurons in the input layer have no transfer function. Logistic sigmoid transfer function (logsig) and linear transfer function (purelin) were used in the hidden layers and output layer of the network as an activation function, respectively.

\subsubsection{Wind energy prediction of pivot target Station}

In this study, the ANN method was applied for the prediction of monthly wind speed of any target station at a location with no measurement, which is referred to as the target station from the measurements of a set of surrounding stations. This study has been applied for regional wind speed prediction in the area of Thaiyur (New location) in the south east coastal area of Tamil Nadu. The location is between two meteorological stations namely Sathyabama University 50m Tower and Anupuram 50m Meteorological station. The latitude is $12^{\circ} .7388^{\prime}$ and longitude is $80^{\circ} .1748^{\prime}$. The elevation of the location is $41 \mathrm{ft}$ from the sea level. In order to estimate a target station, the correlation coefficient was obtained for each pair of wind speed time series of all stations and weighting factors between the pivot station and its surrounding stations were determined by artificial neural network technique.

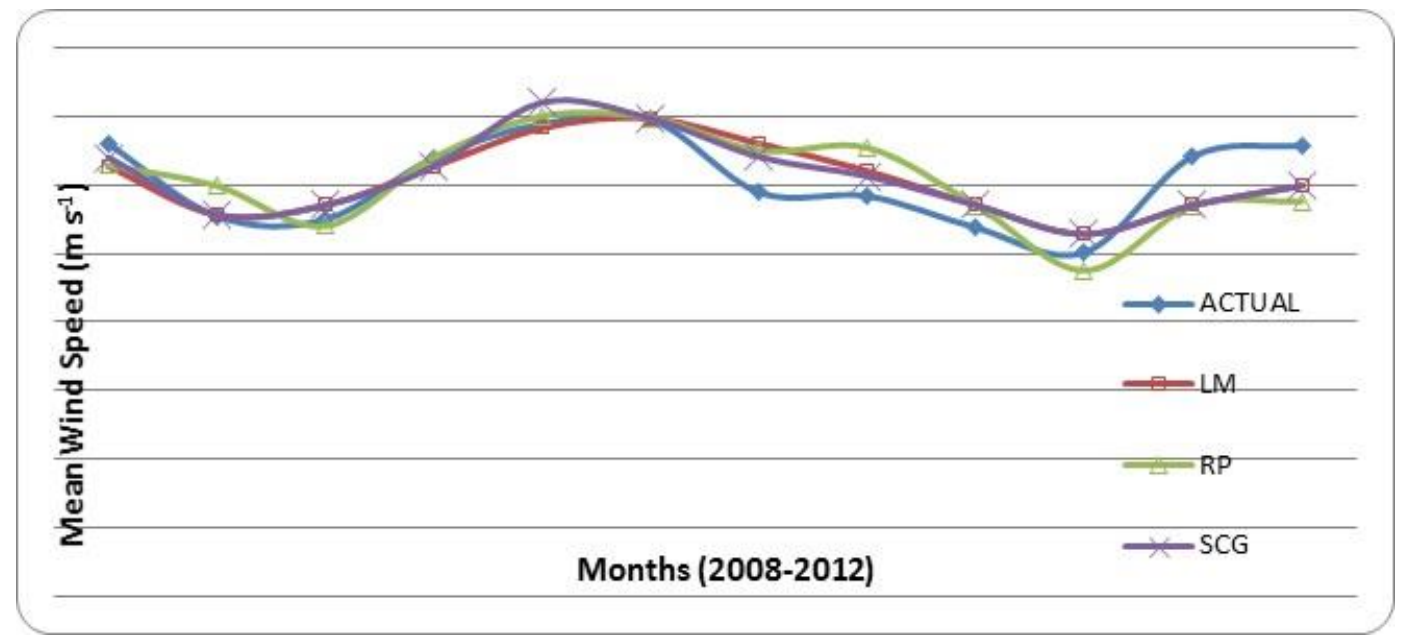

Figure 6. Comparison between monthly prediction of artificial neural network (RP, SCG and LM) and actual results for Anupuram meteorological station 


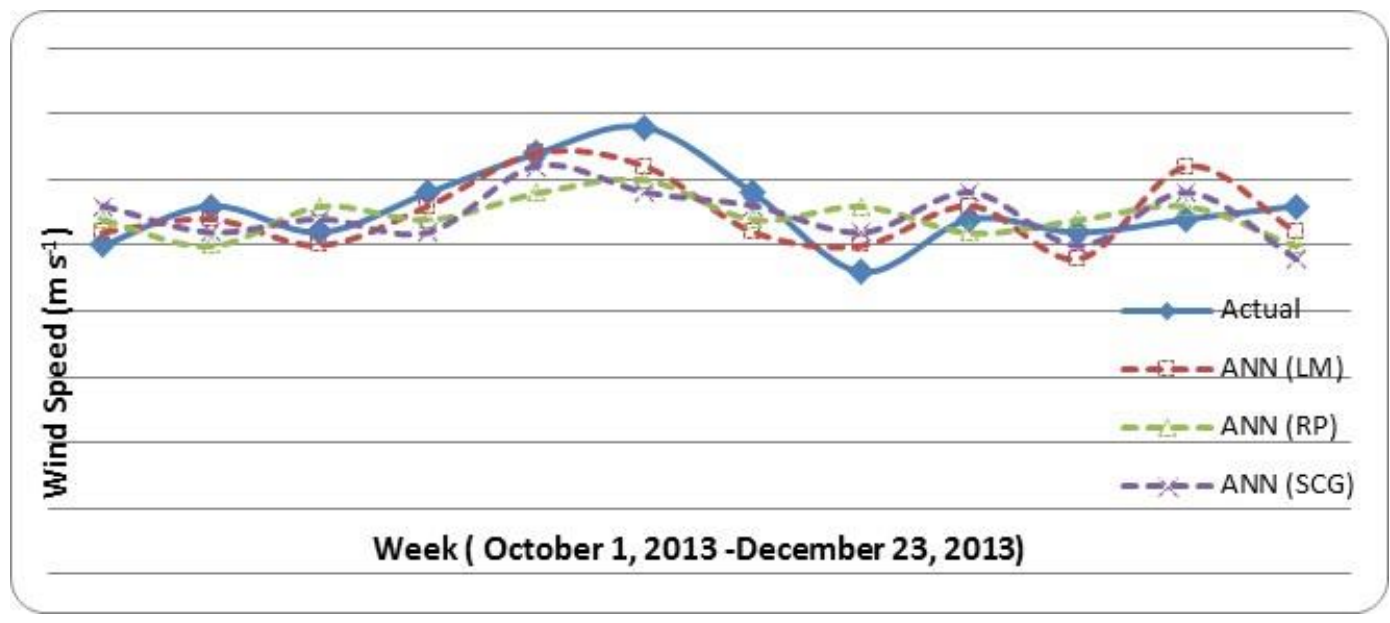

Figure 7. Comparison between weekly prediction of artificial neural network (RP, SCG and LM) and actual results for Anupuram meteorological station

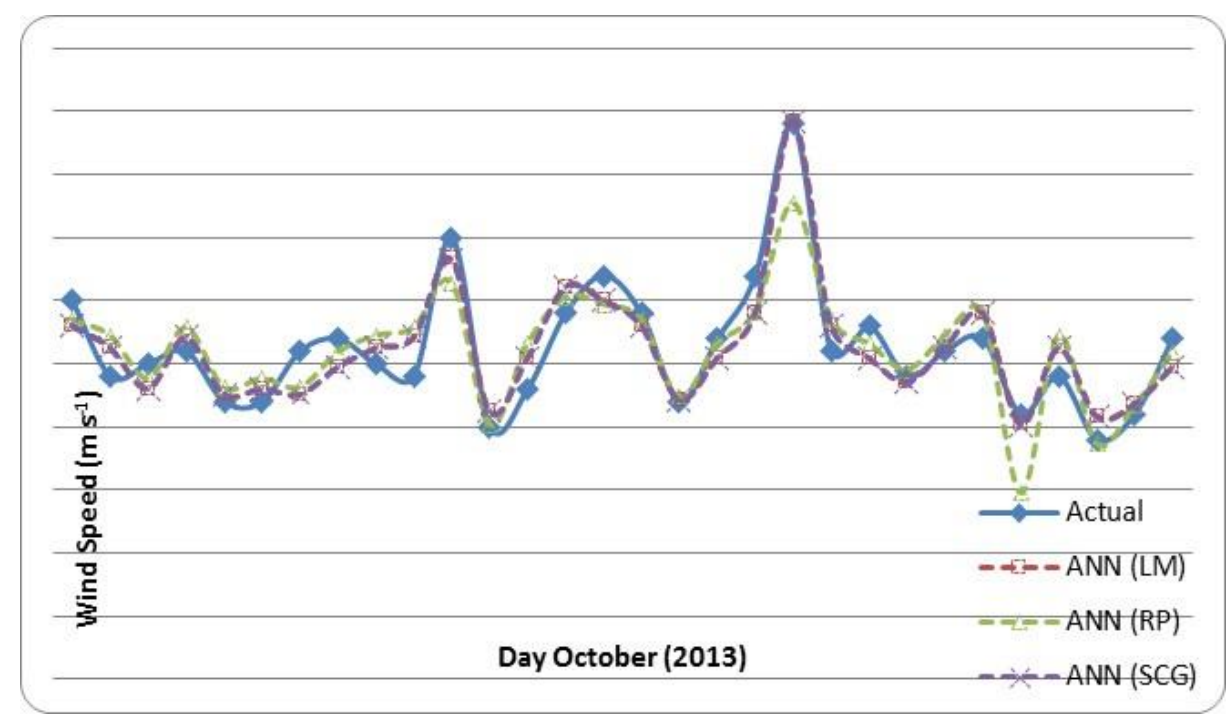

Figure 8. Comparison between Daily prediction of artificial neural network (RP, SCG and LM) and actual results for Anupuram meteorological station

From the $16 \mathrm{~m}$ height of anemometer wind speed data of surrounding stations the mean monthly wind speed of the neighboring stations are nearly close to each other. The following Table 6 . Shows the standard deviations of the surrounding stations are $0.372 \mathrm{~m} \mathrm{~s}^{-1}$ and $0.310 \mathrm{~m} \mathrm{~s}^{-1}$. These shows the deviations are correlated to the pivot station. The mean wind energy potential between the surrounding stations is 16.7 $\mathrm{W} \mathrm{\textrm {m } ^ { - 2 }}$ and $17.7 \mathrm{~W} \mathrm{~m}^{-2}$. The correlation coefficients of monthly wind speed of two stations are 0.8017 .

Table 6. Wind Energy Potential, Standard deviation and Correlation of Surrounding Stations

\begin{tabular}{cccc}
\hline Station & $\begin{array}{c}\text { Mean Wind Speed } \\
\left(\mathrm{m} \mathrm{s}^{-1}\right)\end{array}$ & $\begin{array}{c}\text { Standard } \\
\text { Deviation }\left(\mathrm{m} \mathrm{s}^{-1}\right)\end{array}$ & $\begin{array}{c}\text { Correlation Coefficient } \\
\text { Between two stations }\end{array}$ \\
\hline $\begin{array}{c}\text { Sathyabama University } \\
\text { 50m Tower }\end{array}$ & 2.84 & 0.372 & 0.8017 \\
\hline Anupuram 50m Tower & 3.04 & 0.319 & \\
\hline
\end{tabular}


The Table 7. Shows the statistical errors for RP, SCG and LM learning algorithms. The most significant point in the selection of these the pivot stations is that there is a good relation with high correlation coefficient between the neighboring meteorological stations.

Table 7. Statistical errors for different learning algorithms

\begin{tabular}{lccccccccc}
\hline \multirow{1}{*}{ Station } & \multicolumn{3}{c}{$\begin{array}{c}\text { RP Learning } \\
\text { Algorithm }\end{array}$} & \multicolumn{3}{c}{$\begin{array}{c}\text { SCG Learning } \\
\text { Algorithm }\end{array}$} & \multicolumn{3}{c}{$\begin{array}{c}\text { LM Learning } \\
\text { Algorithm }\end{array}$} \\
\cline { 2 - 10 } & RMSE & $\mathrm{R}^{2}$ & MAPE & RMSE & $\mathrm{R}^{2}$ & MAPE & RMSE & $\mathrm{R}^{2}$ & MAPE \\
\hline $\begin{array}{l}\text { Sathyabama } \\
\begin{array}{l}\text { University } \\
\text { 50m Tower }\end{array}\end{array}$ & 0.68 & 0.99 & 0.71 & 0.63 & 0.99 & 0.07 & 0.62 & 0.99 & 0.07 \\
\hline $\begin{array}{l}\text { Anupuram 50m } \\
\begin{array}{l}\text { Meteorological } \\
\text { Station }\end{array}\end{array}$ & 0.61 & 0.99 & 0.74 & 0.63 & 0.99 & 0.073 & 0.62 & 0.99 & 0.07 \\
\hline
\end{tabular}

\section{Conclusion}

In order to improve the accuracy of simulations in ANN method we have to select wind speed values with similarity correlation factors. Selecting Anupuram meteorological station as a target station, it seems that Sathyabama University meteorological station should be chosen as a reference station due to the high rate of correlation coefficient between the target and reference stations. That is to say, the value of the mean monthly wind speed of Sathyabama University meteorological station was utilized to estimate the mean monthly wind speed of Anupuram meteorological station. Similarly, selecting a new neighborhood pivot station between these two stations that is Thaiyur as a target station, it seems should be chosen as a reference station due to high rate of correlation coefficient between the target and reference stations. It can be concluded that the ANN method seems a powerful tool in predicting the missing wind speed of any location depending on the correlation between target and reference stations. The advantage of this model was that as long as having the required wind speed data of the reference stations, the future wind speed of target station can also be predicted straightaway and satisfactorily without the use of any topographical details or other meteorological data.

\section{References}

Brahmi N., Sallem S., Chaabene M. (2010), ANN based parameters estimation of Weibull: Application to wind energy potential assessment of Sfax, Tunisia, International Renewable Energy Congress November 5-7.

Devi Ch.J., Prasad Reddy B.S., Kumar K.V., Reddy M.B. and Nayak N.R. (2012), ANN Approach for Weather Prediction using Back Propagation, International Journal of Engineering Trends and Technology, 3(1), 19-23.

Guo Zhen-Hai, Wu Jie, Lu Hai-yan and Wang Jian-zhou (2011), A case study on a hybrid wind speed forecasting method using BP neural network, Knowledge-Based Systems, 24, 1048-1056.

Janakiraman R. and Paramasivam S. (2013), Modeling and Simulation of Self Excited Induction Machine for Wind Power Generation, Int. J. on Electrical and Power Engineering, 4(2), 79-84.

Jeyabalan P. (2009), A Study on Power Scenario in Tamil Nadu, Book Chapter, Centre for Asia Studies, 2009

Li G., Shi J. and Zhou J. (2011), Bayesian adaptive combination of short-term wind speed forecasts from neural network models, Renewable Energy, 36, 352-359.

Philippopoulos K. and Deligiorgi D. (2012), Application of artificial neural networks for the spatial estimation of wind speed in a coastal region with complex topography, Renewable Energy, 38, 75-82.

Pillai G.M. (2006), Wind Power development in India, Current Science, 93(4). 